\title{
The potential of multi-compound nanoparticles to bypass drug resistance in cancer
}

\author{
C. G. Da Silva ${ }^{1} \cdot$ Godefridus J. Peters $^{2} \cdot$ Ferry Ossendorp $^{3} \cdot$ Luis J. Cruz $^{1}$
}

Received: 4 May 2017 / Accepted: 29 August 2017 / Published online: 8 September 2017

(C) The Author(s) 2017. This article is an open access publication

\begin{abstract}
Purpose The therapeutic efficacy of conventional chemotherapy against several solid tumors is generally limited and this is often due to the development of resistance or poor delivery of the drugs to the tumor. Mechanisms of resistance may vary between cancer types. However, with current development of genetic analyses, imaging, and novel delivery systems, we may be able to characterize and bypass resistance, e.g., by inhibition of the right target at the tumor site. Therefore, combined drug treatments, where one drug will revert or obstruct the development of resistance and the other will concurrently kill the cancer cell, are rational solutions. However, drug exposure of one drug will defer greatly from the other due to their physicochemical properties. In this sense, multi-compound nanoparticles are an excellent modality to equalize drug exposure, i.e., one common physicochemical profile. In this review, we will discuss novel approaches that employ nanoparticle technology that addresses specific mechanisms of resistance in cancer.

Methods The PubMed literature was consulted and reviewed.

Results Nanoparticle technology is emerging as a dexterous solution that may address several forms of resistance in cancer. For instance, we discuss advances that address
\end{abstract}

Luis J. Cruz

1.j.cruz_ricondo@lumc.nl

1 Translational Nanobiomaterials and Imaging, Department of Radiology, Bldg.1, C2-187h, Leiden University Medical Centre, Albinusdreef 2, 2333 ZA Leiden, The Netherlands

2 Department of Medical Oncology, VU University Medical Center, Amsterdam, The Netherlands

3 Department of Immunohematology and Blood Transfusion, Leiden University Medical Centre, Leiden, The Netherlands mechanisms of resistance with multi-compound nanoparticles which co-deliver chemotherapeutics with an antiresistance agent. Promising anti-resistance agents are (1) targeted in vivo gene silencing methods aimed to disrupt key resistance gene expression or (2) protein kinase inhibitors to disrupt key resistance pathways or (3) efflux pumps inhibitors to limit drug cellular efflux.

Keywords Multi-compound nanoparticles · Resistance mechanisms in cancer - Cancer · Protein kinase inhibitor . siRNA · Drug delivery $\cdot$ Targeting $\cdot$ Drug release .

Nanomedicine

\section{Introduction}

Nanoparticles are emerging as ideal candidates for targeted delivery of drugs. A novel development is nanoparticles capable to encapsulate or bind multiple compounds at once and release the drugs at the target site either simultaneously or in a predetermined sequence. Nanoparticles are commonly composed of organic or inorganic materials with sizes ranging from 10 to $1000 \mathrm{~nm}(\mathrm{~nm})$ and are generally $500 \mathrm{~nm}$ or smaller. Organic nanoparticles are usually composed of biodegradable polymers [1-5] or lipids [6], whereas inorganic nanoparticles are usually composed of gold, silver, titanium dioxide, iron, carbon, or silicon [7-9].

Nanoparticles as drug delivery agents have several advantages compared to 'free' drugs, including reduced bio-distribution, sustained and slow release, and protect drugs against degradation thereby prolonging drug half-life. A tissue wide bio-distribution of a drug is often unwanted, as the drug will not only go to the site of interest but also go to many other tissues, inducing dose limiting side effects. The consequence is that the critical dose is therefore not attainable and the 
efficacy of the drug is reduced. In contrast to 'free' drugs, nanoparticles can increase drug blood circulation time considerably by protecting the drug from rapid catabolism by detoxification enzymes and body clearance. In addition, nanoparticles can widen the drug repertoire to the clinic to include abandoned potent putative drugs. These include drugs with (1) a low therapeutic index, or (2) that are very hydrophobic and due to poor solubility were regarded as unsafe for in vivo application, or (3) in their 'free' form that would be degraded too rapidly, or (4) that become instable, or (5) that accumulate in organs of disinterest thereby inducing severe toxicity. Nanoparticles are also increasingly modified with targeting moieties to mitigate side effects to increase their efficacy even further. The targeting moieties are designed to increase cell type specificity by targeting molecules such as peptides, ligands, or antibodies to cellspecific receptors thereby enhancing specific uptake by receptor-mediated endocytosis or increasing local retention time.

Nanoparticles have clear advantages and their adoption for medical usage is emerging, as more than 40 therapeutic nanoparticles have been approved for the application in the clinic worldwide and at least 200 more are in clinical trials [10-12]. Although nanoparticles for drug delivery have several advantages over 'free' drugs, there are also some disadvantages, which may differ greatly from type-to-type of nanoparticle [13, 14]. For instance, while nanoparticles may help to reduce tissue wide bio-distribution, it is also this feature that is limiting its access to tissues that are located beyond blood vessels and filter organs, which limits the application of nanoparticles for some pathologies. For the specific treatment of solid tumors, however, a phenomenon entitled 'Enhanced Permeability and Retention' (EPR) effect, occasionally observed in human cancers, may be exploited to circumvent this obstacle [15]. The EPR effect is characterized by leaky blood vessels at the tumor site, originating from unregulated secretion of angiogenic factors, and decreased lymphatic drainage. Although the EPR effect is not always present or found very pronounced in humans, it may be induced or augmented in some specific cases, allowing nanoparticles to extravasate and still gain access to cancer cells [16-18]. An important disadvantage of some nanoparticle types is possibly organ specific toxicity, due to their propensity to accumulate in filter organs, such as liver and kidney, or spleen and lungs, although the degree of accumulation may vary considerably from typeto-type [19]. Nanoparticle surface modifications, such as amalgamation of polyethylene glycol (PEG) polymer chains (PEGylation; PEG) or adjusting the physicochemical properties, can attenuate this accumulation and therefore reduce toxicity in these organs. However, the demand for innovation maintains the pressure to continuously design novel and dexterous formulations to overcome these disadvantages and further exalt the therapeutic potential of nanoparticles to the clinic [20, 21]. For the treatment of cancer, several genotoxic and cytotoxic drugs are being encapsulated into or bound to nanoparticles to increase their efficacy and reduce side effects. For example, Doxil ${ }^{\circledR}$, Abraxane $^{\circledR}$, and more recently Onivyde ${ }^{\circledR}$ were approved and are clinically available nanoparticle formulations of doxorubicin, paclitaxel, and irinotecan, respectively. These modalities may be superior to their 'free' counterparts, either because of their specific delivery preventing, e.g., cardiotoxicity (Doxil) or activation at their target site. However, they do not specifically deal with existing or evolving mechanisms of resistance. As treatment resistance commonly arises in cancer, there is a dire need of a more 'sophisticated' class of drugs that are able to address these treatment impediments. Here onwards, this review will focus on recent developments of (multi-compound) nanoparticle modalities that, in addition to kill cancer cells, may be employed to prevent or circumvent evolving mechanisms of resistance in cancer.

\section{Mechanisms of resistance in cancer}

A few cancer types, such as chorionic carcinoma, seminoma, and some (sub) types of lymphoma, actually respond well to cytostatic chemotherapy, commonly leading to clinical remission and cancer cures. Unfortunately, the vast majority of solid tumors will not respond as favorably. This is generally mediated by intrinsic resistance to cytotoxic drugs after an initial reduction of the tumor mass [22]. As tumors are quite heterogeneous of composition, it is not completely clear whether drug resistance is attained exclusively by clonal selection, i.e., selection of mutants resistant to the drug, a certain degree of adaptation or both [23]. Common mechanisms of resistance include pathway rewiring to accommodate enhanced proliferation, anti-apoptosis, and pro-survival signals, enhanced drug efflux and reduced influx, acquired (additional) DNA mutations, enhanced DNA repair, epithelial to mesenchymal phenotype transition, epigenetic modifications, drug inactivation, and drug target alteration, among others [24].

For example, a common aberrantly activated and pharmaceutically targeted pathway in cancer is the mitogenactivated protein kinase (MAPK) signaling pathway. This pathway provides strong survival and proliferative signals, effectively antagonizing the induction of apoptosis triggered by many oncological drugs [25]. Several signaling pathways, including the MAPK pathway, converge in the activation of the c-Myc gene that is frequently found overexpressed and mutated in a vast range of cancer types [26-29]. The Myc protein is a basic helix-loop-helix transcription factor controlling efficient proliferation of somatic and germ cells. Unfortunately, Myc has been defined to be lacking targetable 
active sites for drugs and therefore considered 'undruggable' for conventional pharmaceuticals. Another protein involved in survival and conferring drug resistance in cancer is the epidermal growth factor receptor (EGFR), often found aberrantly (over)expressed in carcinomas.

A distinct and predominant mechanism of drug resistance found in cancer cells is the overexpression of specific efflux pumps. These efflux pumps are part of the ABC superfamily of transporters and can translocate substrates (drugs) from the inside to the outside of the cell, thereby reducing intracellular drug accumulation. Currently, there are 49 human ABC transporter proteins described. From these 49 transporters, 15 are commonly associated with cancer and conferring resistance to chemotherapeutic agents. $P$-glycoprotein, BCRP, and MRP1 are among the most described efflux pumps to play a key role in multidrug resistance (MDR)mediated resistance in cancer [30].

Some of these mechanisms of resistance may be addressed by employing specifically adapted nanoparticles. The number of scientific publications of nanoparticles for single drug delivery is immense and their therapeutic potential is evident; however, novel strategies are required to improve cancer therapy efficacy to deal with evolving mechanisms of resistance. To achieve this goal, the delivery of several drugs, with a diverse mode of action, may be combined in nanoparticles (see Fig. 1 for an illustration). Additionally, the required level of control over the drug release time and release sequence is for this demanding task considerably higher. Notably, as the complexity of chemical assembly of such nanoparticles raises, so may the costs for GMP mass production and the costs of QA/QC [31]. In addition, the FDA/CDER approval of multi-compound nanoparticles may, in some specific cases, be more complex and slower to attain due to their polyvalent nature [31, 32].

\section{Targeting mechanisms of resistance with protein kinase inhibitors nanoparticle formulations}

Several drugs are currently in the clinic or are being developed that can inhibit or repress specific mechanisms of resistance. These drugs are so-called small molecule inhibitors, anti-signaling drugs, or biologicals, e.g., protein kinase inhibitors (PKIs) and monoclonal antibodies. However, the cure rate of solid tumors by these modalities alone is low and acquired resistance occurs as well [33]. In addition, chronic administration is often required leading to toxicity over time. It appears that, similar to conventional chemotherapy, PKIs that are encapsulated in nanoparticles also induce less side effects, compared to 'free' PKI drug administration. For instance, poly (lactic-co-glycolic acid; PLGA) nanoparticles encapsulating erlotinib induced significantly less sub-acute toxicity in Wistar rats compared to 'free' administration [34]. In a similar study, Marslin et al. [35] have shown that cardiotoxicity, often a complication of prolonged administration of imatinib mesylate, could be avoided by encapsulating this drug in PLGA nanoparticles while increasing the efficacy compared to the 'free' drug.

Instead of monotherapy, a rational combination of PKIs with other drugs may harbor great synergetic potential. Some combinations may enhance cancer treatment efficacy by predisposing tumors to conventional chemotherapy. For example, Basu and colleagues [36] assembled nanoparticles carrying PD98059, a selective MAPK inhibitor, to predispose cancer cells dependent on this oncogenic pathway to chemotherapy. The authors combined the nanoparticles containing PD98059 with cisplatin and observed an impressive tumor growth disparity compared to either compound alone. A clear synergistic effect was observed when these compounds were combined for simultaneous delivery to melanoma cells in vivo. Although the concurrent administration of these two modalities was beneficial in this setting, it may
Fig. 1 Schematic representation of distinct types of nanoparticle approaches. a Mono-chemotherapy nanoparticle approach containing one type of drug without targeting moieties; $\mathbf{b}$ depiction of a multidrug nanoparticle approach with active targeting moieties

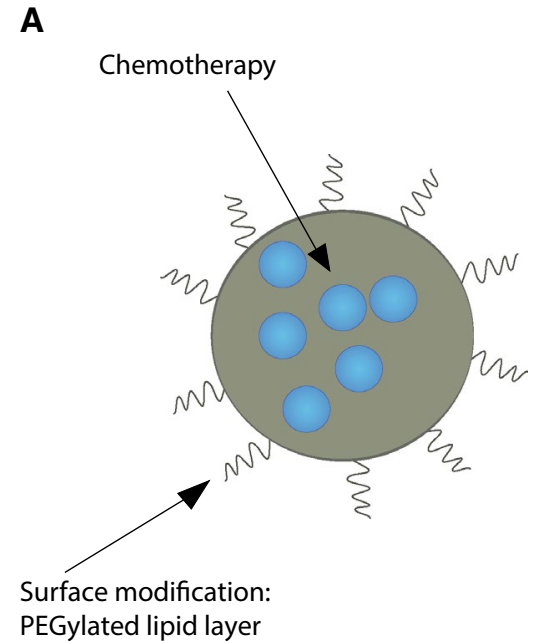

B

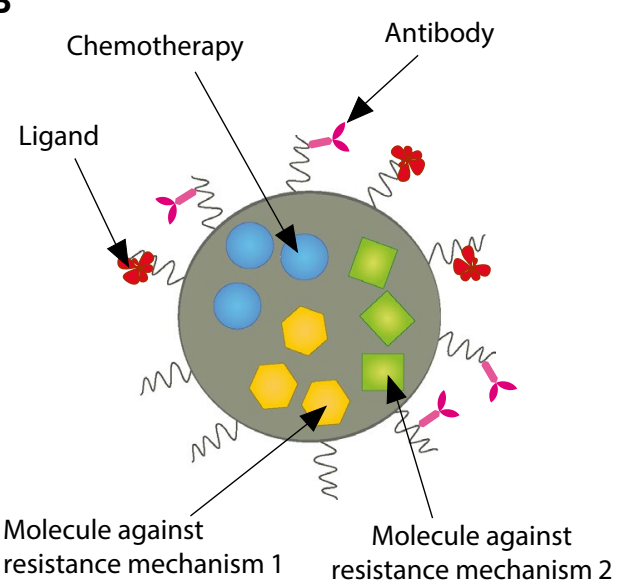


differ with PKI, cancer, and chemotherapy type. Lee et al. [37] have recently shown that sequential administration, but not simultaneous, may be crucial for some PKIs and conventional chemotherapy combinations. The authors showed that pre-treatment of breast cancer cells with erlotinib, a targeted EGFR inhibitor, was required to sensitize cancer cells to doxorubicin and that co-administration of both (i.e., erlotinib and doxorubicin simultaneously) was not nearly as effective. By inhibiting EGFR, the cancer cell re-acquired a working apoptosis pathway responsive to DNA damage. Furthermore, Morton et al. [38] described how liposomes could be employed to achieve such time controlled release of drugs. By loading doxorubicin into the hydrophilic core and entrapping erlotinib in the hydrophobic compartment of the membrane, erlotinib is released before doxorubicin. The sequential release effectively forces an internal rewiring of signaling pathways effected by erlotinib before DNA damage is induced by doxorubicin. This incites the cancer cell proneness toward apoptosis considerably. Figure 2 illustrates a putative modality to circumvent multiple mechanisms of resistance in cancer.

This elegant approach achieved a much higher rate of cancer cell killing by hampering the cancer cells resistance mechanisms against apoptosis before releasing the cellkilling agent. Au et al. [39] recently showed that sequential release of drugs for cancer therapy is also possible with polymer nanoparticles, by incorporating the hydrophobic drugs wortmannin and docetaxel into an adapted formulation of PLGA-PEG nanoparticles. Wortmannin inhibits, non-exclusively, the phosphoinositide 3 kinases (PI3Ks), in essence sensitizing cancer cells to apoptosis, allowing docetaxel to successfully disrupt cell division. The PI3K and the earlier mentioned MAPK pathway are actually survival pathways preventing chemotherapeutic drugs to induce cell

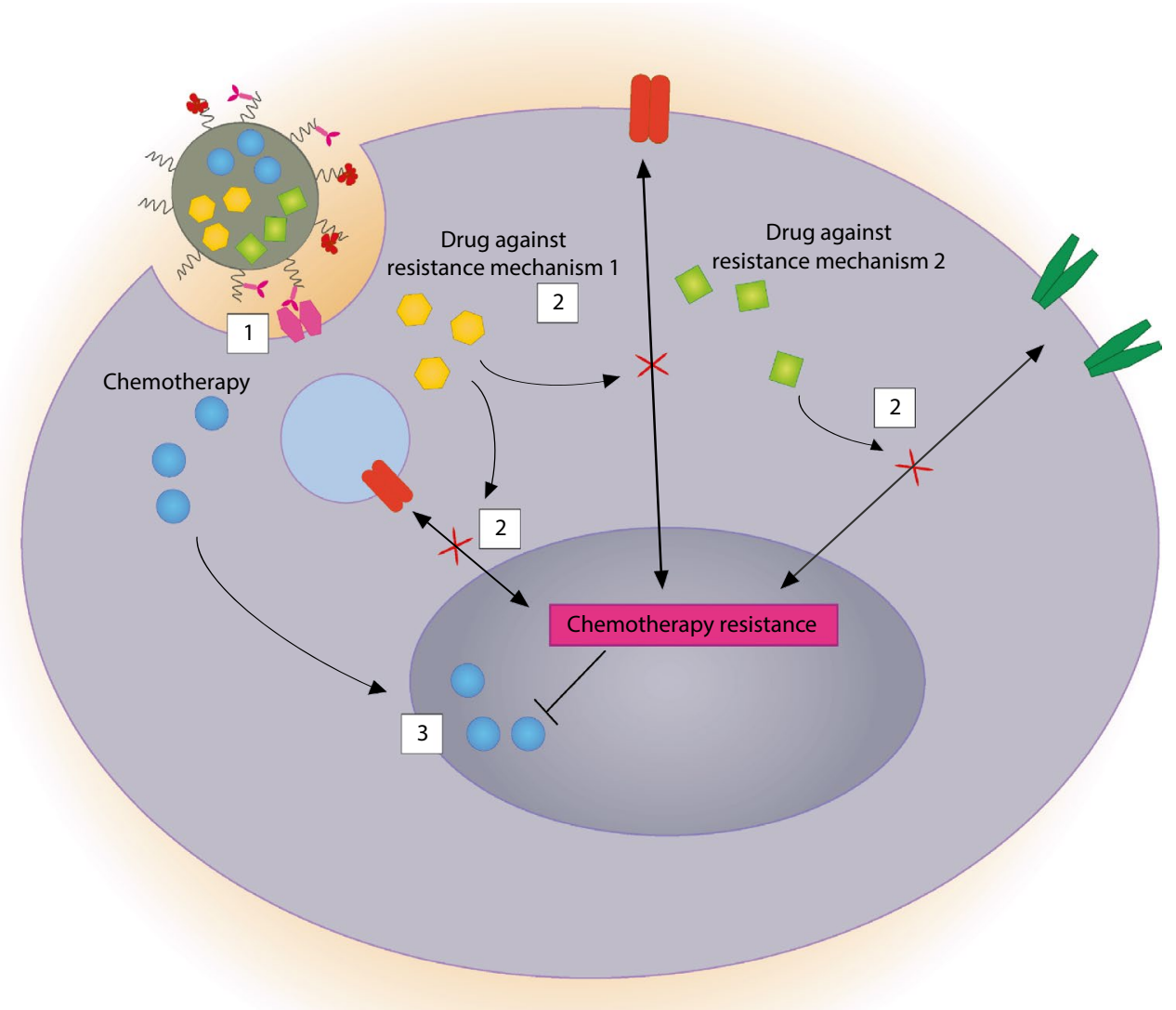

Fig. 2 Schematic representation of a putative multi-compound nanoparticle that releases multiple compounds simultaneously or in sequence. $1 \mathrm{~A}$ targeted nanoparticle triggers the receptor-mediated endocytosis uptake of the nanoparticle by the target cell; 2 after intracellular processing of the nanoparticle (not depicted), selective small molecule compounds are released that inhibit mechanisms of resistance either simultaneously or in sequence, depending on the nanoparticle design. In this illustration, two distinct drugs 'Drug against resistance mechanism' 1 and 2 are depicted, each suppressing a different mechanism of resistance. One of these drugs could inhibit efflux pumps, to ascertain that chemotherapy is not excreted from the cell, while the second drug could suppress an (active) anti-apoptotic pathway hindering cell death related to DNA damage. 3 Cell cycle is disrupted by conventional chemotherapy by inducing DNA damage and trigger apoptosis that can now be executed unobstructed due to the inhibited anti-apoptotic pathway and the cancer cell dies 
death; therefore, inhibition of these survival pathways will activate the chemotherapeutic drug and cell death [40]. As the molecular weight of wortmannin is lower compared to docetaxel, it was released prior to docetaxel, allowing a controlled sequential release of these drugs. Also in this setting, the pathway rewiring process before interfering with cell division was essential. Several other combined nanoparticle and protein kinase inhibitor strategies are emerging and are summarized in Table 1.

Cancer cells rapidly develop resistance against PKIs commonly by the activation of compensatory pathways or target site mutations [41]. For instance, it has been described that inhibition of the EGFR pathway with PKIs may eventually induce the activation of the insulin-like growth factor 1 (IGF-1R) pathway, as an acquired method of resistance.

Table 1 Nanoparticle protein kinase inhibitor delivery targeting pathways involved in therapy resistance

\begin{tabular}{|c|c|c|c|c|c|c|}
\hline Nanoparticle type & Active targeting & PKI & $\begin{array}{l}\text { Primary kinase } \\
\text { targeted }\end{array}$ & Other compounds & Model & References \\
\hline $\begin{array}{l}\text { Accurin polymer } \\
\text { based }\end{array}$ & - & AZD2811 & Aurora B kinase & & $\begin{array}{l}\text { Human colon } \\
\text { cancer }\end{array}$ & {$[83]$} \\
\hline $\begin{array}{l}\text { Glutaraldehyde } \\
\text { crosslinked } \\
\text { albumin }\end{array}$ & $\begin{array}{l}\text { Anti-EGFR } \\
\text { nanobody }^{\mathrm{a}}\end{array}$ & $\begin{array}{l}17864 \text { (platinum- } \\
\text { bound sunitinib } \\
\text { analog) }\end{array}$ & PDGF-R/VEGFR & & $\begin{array}{l}\text { Human head and } \\
\text { neck squamous } \\
\text { cell carcinoma (in } \\
\text { vitro) }\end{array}$ & [84] \\
\hline Gold & - & Erlotinib & EGFR & & $\begin{array}{l}\text { Human adenocar- } \\
\text { cinoma and non- } \\
\text { small-cell lung } \\
\text { cancer (in vitro) }\end{array}$ & {$[85]$} \\
\hline Gold & $\begin{array}{l}\text { Anti-EGFR anti- } \\
\text { body }^{\text {a }}\end{array}$ & Gefitinib & EGFR & & $\begin{array}{l}\text { Lung cancer (in } \\
\text { vitro) }\end{array}$ & [86] \\
\hline Hexadentate-PLGA & - & PD98059 & MEK & $\begin{array}{l}\text { Cisplatin (not in } \\
\text { nanoparticle) }\end{array}$ & $\begin{array}{l}\text { Melanoma and lung } \\
\text { carcinoma }\end{array}$ & {$[36]$} \\
\hline Iron oxide/magnetite & - & AM-005 + AT-9283 & Aurora kinase & & Liver cancer & [87] \\
\hline Liposomal & - & WHI-131 & JAK3/EGFR & & $\begin{array}{l}\text { Human B-lineage } \\
\text { ALL/breast cancer }\end{array}$ & {$[88,89]$} \\
\hline Liposomal & $\begin{array}{l}\text {-/Anti-CD19 anti- } \\
\text { body }^{\text {a }}\end{array}$ & $\begin{array}{l}\text { SYK-P-site inhibitor } \\
\text { C61 }\end{array}$ & SYK & & $\begin{array}{l}\text { B-precursor acute } \\
\text { lymphoblastic } \\
\text { leukemia }\end{array}$ & [90-92] \\
\hline Liposomal & $\begin{array}{l}\text { Anti-EGFR nano- } \\
\text { body }{ }^{\text {a }}\end{array}$ & AG538 & IGF-1R & & $\begin{array}{l}\text { Human head and } \\
\text { neck squamous } \\
\text { cell carcinoma } \\
\text { and breast adeno- } \\
\text { carcinoma }\end{array}$ & [42] \\
\hline Liposomal & Folate & Erlotinib & EGFR & Doxorubicin & $\begin{array}{l}\text { Human breast and } \\
\text { lung cancer }\end{array}$ & {$[38]$} \\
\hline $\begin{array}{l}\text { Liposomal (layer- } \\
\text { by-layer) }\end{array}$ & $\mathrm{CD} 44^{\mathrm{a}}$ & $\begin{array}{l}\text { Selu- } \\
\text { metinib + PX-866 }\end{array}$ & $\mathrm{MEK} 1 / 2$ + PI3 K & & $\begin{array}{l}\text { Human breast } \\
\text { cancer }\end{array}$ & {$[93]$} \\
\hline Oleic acid based & - & AZD6244 & MAPK & Cisplatin & $\begin{array}{l}\text { Human cervical/ } \\
\text { breast/liver cancer } \\
\text { (in vitro) }\end{array}$ & [94] \\
\hline $\begin{array}{l}\text { PLGA-PEG di- } \\
\text { block copolymer }\end{array}$ & - & Wortmannin & PI3 K & Docetaxel & $\begin{array}{l}\text { Human lung and } \\
\text { prostate cancer }\end{array}$ & [39] \\
\hline PLGA & - & LY294002 & PI3 K & & $\begin{array}{l}\text { Murine melanoma } \\
\text { and human breast } \\
\text { cancer }\end{array}$ & {$[95]$} \\
\hline Reverse micelles & - & Erlotinib & EGFR & & $\begin{array}{l}\text { Pancreatic adeno- } \\
\text { carcinoma (in } \\
\text { vitro) }\end{array}$ & [96] \\
\hline
\end{tabular}

$E G F R$ epidermal growth factor receptor, $I G F-1 R$ insulin-like growth factor 1 receptor, JAK3 Janus kinase $3, M E K$ mitogen-activated protein kinase, $P D G F-R$ platelet-derived growth factor receptor, $P I 3 K$ phosphoinositide 3-kinase, $P L G A$ poly(lactic-co-glycolic acid), $S Y K$ Spleen tyrosine kinase, VEGFR vascular endothelial growth factor receptor

${ }^{a}$ Activate targeting with dual role: (1) NP targeting moiety and (2) direct perturbing mechanism of resistance by receptor agonism/antagonism or may trigger antibody mediated cytotoxicity 
To address this adaptation, Van der Meel et al. [42] developed liposomes carrying an anti-IGF-1R kinase inhibitor and coated the liposomes with antagonistic anti-EGFR nanobodies. This approach led to considerable less pro-survival and proliferation signaling in cancer cells. The majority of the studies summarized in Table 1 describe nanoparticle approaches to target oncogenic pathways, often implicated in cancer mechanisms of resistance. Most of these studies did not combine nanoparticles with 'conventional' chemotherapy. However, combining PKIs with chemotherapy may hold a considerable therapeutic benefit, as indicated by the combinatorial studies described above.

In summary, several PKIs have less favorable physicochemical properties that decrease their therapeutic potential [43] and encapsulation of PKIs into nanoparticles appears to be a viable strategy to circumvent some of these limitations. In addition, PKI-associated toxicity may be reduced [34]. Nonetheless, it appears that combining nanoparticle formulated PKIs with conventional chemotherapy could be an effective strategy to hinder therapy-induced resistance. It also appears evident that the order of administration is paramount for the efficacy of the treatment modality for some cancer types; sequential rather than simultaneous and PKI exposure before cytotoxic agent.

\section{Targeting mechanisms of resistance with silencing RNA nanoparticle formulations}

Several mechanisms of resistance in cancer have been previously targeted by suppression of specific gene expression, most commonly by small interfering RNA (siRNA) or to a lesser extent small hairpin RNA (shRNA) delivery to cancer cells. An siRNA molecule is a double-stranded RNA molecule of 20-25 base pairs whereby its sequence is complementary to a part of its target gene mRNA transcript. It is often employed to disrupt the translation of a specific gene transcript into protein by exploiting the RNA interference pathway [44].

Traditionally, gene therapy treatment with siRNA is performed by the injection of 'naked' siRNA directly into the bloodstream or packed in modified viruses [45, 46]. Specifically, the targeting of 'naked' siRNA to the cells of interest without the use of a delivery agent is generally found inefficacious as it is rapidly cleared from the bloodstream due to degradation by serum nucleases and renal clearance. In contrast, adapted viruses are, in comparison, quite efficacious delivery agents for siRNA; however, immune responses against the viral proteins abstains the efficacy of this modality [47]. As an alternative, nanoparticles can encapsulate, protect, and deliver siRNA intracellularly. Conversely, nanoparticles have limitations as well, as described in the first section of this paper, and are applicable to siRNA delivery as well, i.e., mainly the dependence of EPR effect to gain access to cancer cells in solid tumors. From an immunological perspective, immune responses against nanoparticles have been sparsely studied and may vary greatly from type and composition. For instance, nanoparticles containing 1,2-Dioleoyl-3-trimethylammonium-propane (DOTAP), mainly an ingredient for cationic liposomes, has been reported to induce potent type I and type II interferon responses [48]. However, PEGylation of nanoparticles reduces immunogenicity without the formation of any additional toxic metabolites and appears essential for successful prolonged blood circulation [20, 49]. A multifold of-monotherapeutic-nanoparticle formulations that aim to modulate driver oncogenes have also been reported but are beyond the scope of this review. Multi-compound nanoparticles targeting specifically mechanisms of resistance by targeted siRNA gene silencing in cancer are summarized in Table 2.

Similar to previously discussed PKIs nanoparticle modalities, combining specific siRNA treatment with 'conventional' chemotherapy appears to yield superior results than any of the modalities alone. For instance, Yoon et al. [50] designed two glycol chitosan-based nanoparticles, one containing doxorubicin and another containing siRNA targeted to the $\mathrm{Bcl}-2$ gene transcript. As Bcl-2 is involved in conferring resistance against apoptosis triggered by doxorubicin, durable in vivo tumor growth repression was observed after repeated injections of the nanoparticles containing doxorubicin followed by the nanoparticles containing the $\mathrm{Bcl}-2$ siRNA. Moreover, combinatorial targeted nanoparticle delivery approaches of chemotherapy and siRNA targeted against (driver) oncogenes are highly anticipated. One of such oncogenes is the c-Myc gene. For instance, Zhang et al. $[51,52]$ recently combined gemcitabine monophosphate and c-Myc siRNA in one nanoparticle to efficiently suppress both subcutaneous and orthotopic human lung cancer growth in vivo with minimum toxicity in nude mice. As the involvement of c-Myc is quite prevalent in cancer, a prudent combinatorial nanoparticle approach of chemotherapy and c-Myc siRNA may therefore hold great potential to become one single potential treatment for a wide range of cancers of diverse etiology. The authors also combined gemcitabine monophosphate with VEGF siRNA and found increased efficacy as well. This system had an additional advantage since gemcitabine monophosphate delivery would bypass resistance due to decreased activation [53-55].

\section{Targeting efflux pump and other mechanisms of multidrug resistance with nanoparticle formulations}

Dose escalation is a common pharmacological strategy to overcome mechanisms of resistance mediated by drug 
Table 2 Nanoparticle small interfering RNA delivery targeting pathways involved in therapy resistance

\begin{tabular}{|c|c|c|c|c|c|}
\hline Nanoparticle type & Active targeting & $\operatorname{siRNA}^{\mathrm{a}}$ & Compounds $^{\mathrm{a}}$ & Model & References \\
\hline Glycol chitosan & - & Bcl-2 & Doxorubicin & Human prostate cancer & {$[50]$} \\
\hline LCP & - & c-Myc & $\begin{array}{l}\text { Gemcitabine monophos- } \\
\text { phate }\end{array}$ & Human lung cancer & {$[51]$} \\
\hline LCP & $\begin{array}{l}\text { Anisamide to sigma recep- } \\
\text { tors }\end{array}$ & VEGF & $\begin{array}{l}\text { Gemcitabine monophos- } \\
\text { phate }\end{array}$ & Human lung cancer & {$[52]$} \\
\hline Liposomal & - & MRP1/BCL2 & Doxorubicin & $\begin{array}{l}\text { Human ovarian, breast, } \\
\text { lung and colon cancer. (in } \\
\text { vitro) }\end{array}$ & [97] \\
\hline Liposomal & $\begin{array}{l}\text { Asparagine-glycine-argi- } \\
\text { nine peptide to CD13 }\end{array}$ & $\mathrm{c}-\mathrm{Myc}$ & Doxorubicin & Human fibrosarcoma & [98] \\
\hline Liposomal & $\begin{array}{l}\text { Anisamide to sigma recep- } \\
\text { tors }\end{array}$ & VEGF/c-Myc & Doxorubicin & Human ovarian cancer & [99] \\
\hline Liposomal & GC4 scFv antibody & c-Myc/MDM2/VEGF & miR-34a & Murine melanoma & {$[100]$} \\
\hline Liposomal & - & Mcl1 & SAHA (Vorinostat) & Human cervical cancer & {$[101]$} \\
\hline Liposomal & - & MRP1/BCL2 & Doxorubicin & Human lung cancer & [102] \\
\hline Liposomal & - & BCL2 & d-(KLAKLAK) $)_{2}$ peptide & Murine melanoma & [103] \\
\hline Liposomal & Hyaluronic acid & MRP1 & Doxorubicin & Human breast cancer & [104] \\
\hline DSPE-PEG lipid & Folate & Survivin & Docetaxel & Human liver cancer & [105] \\
\hline Micellar & - & HIF-1 $\alpha$ & $\begin{array}{l}\text { Doxorubicin (combined } \\
\text { treatment; i.e., not in } \\
\text { delivery vehicle) }\end{array}$ & Human prostate cancer & [106] \\
\hline Micellar & - & Plk1 & Paclitaxel & Human breast cancer & [107] \\
\hline Minicell & EGFR antibody & MDR1 & Doxorubicin & Uterine cancer & {$[108]$} \\
\hline PDHA & - & Snail/Twist & Paclitaxel & Murine breast cancer & [109] \\
\hline PEI-GO & - & Bcl-2 & Doxorubicin & $\begin{array}{l}\text { Human cervical cancer } \\
\text { In vitro study only }\end{array}$ & {$[110]$} \\
\hline $\mathrm{PEO}-\mathrm{PbAE} / \mathrm{PCL}$ & - & P-glycoprotein & Paclitaxel & $\begin{array}{l}\text { Human ovarian cancer } \\
\text { (in vitro) }\end{array}$ & [111] \\
\hline PLGA-PEI & Biotin to biotin receptors & P-glycoprotein & Paclitaxel & Murine breast cancer & [112] \\
\hline PLGA & - & DCAMKL-1 & $\begin{array}{l}\text { DAPT (combined treat- } \\
\text { ment; i.e., not in delivery } \\
\text { vehicle) }\end{array}$ & Human colorectal cancer & [113] \\
\hline PLGA & - & REV1/REV3L & Cisplatin prodrug & Human prostate cancer & [114] \\
\hline Mesoporous silica & - & Bcl-2 & Doxorubicin & $\begin{array}{l}\text { Human ovarian cancer } \\
\text { (in vitro) }\end{array}$ & [115] \\
\hline Mesoporous silica & - & P-glycoprotein & Doxorubicin & Human cervical cancer & [116] \\
\hline Mesoporous silica & $\begin{array}{l}\text { Hyaluronic acid + PEGA- } \\
\text { pVEC peptide }\end{array}$ & CTGF & Doxorubicin & Human breast cancer & [117] \\
\hline
\end{tabular}

$B C L 2$ B cell lymphoma 2, $C T G F$ connective tissue growth factor, DAPT $N$-[N-(3,5-difluorophenacetyl)-1-alanyl]-S-phenylglycine t-butyl ester, $D C A M K L-1$ Doublecortin-like and CAM kinase-like 1, DSPE Distearoyl-phosphatidylethanolamine, HIF-1 $\alpha$ Hypoxia-inducible factor-1 $\alpha, L C P$ lipid/calcium/phosphate, MDR1 multidrug resistance 1, MRP1 multidrug resistance-associated protein 1, $P E I-G O$ polyethylenimine-functionalized graphene oxide, $P E G$ ethylene glycol, $P E O-P b A E$ poly(ethylene oxide)-modified poly(beta-amino ester), $P D H A$ poly[(1,4-butanediol)diacrylate- $\beta$-5-hydroxyamylaminel, $P E O-P C L$ Poly(ethylene oxide)-modified poly(epsilon-caprolactone), $P L G A$ poly(lactic-co-glycolic acid), PLGA-PEI PLGA polyethyleneimine, Plkl polo-like kinase 1, SAHA suberoylanilide hydroxamic acid, $s c F v$ single chain fragment variable, $V E G F$ vascular endothelial growth factor

${ }^{a}$ Compounds are encapsulated in delivery vehicles unless stated otherwise

efflux pumps. While an effective approach, it is commonly accompanied by deleterious adverse effects. For instance, doxorubicin effective dose is limited by severe cardiotoxicity [56]. The upregulation of efflux pumps is a common and yet distinct method of resistance against cancer therapy. The upregulation of efflux pumps, such as the $P$-glycoprotein but more importantly MRPs and BCRP (ABCG2) [57], reduces the intracellular accumulation of specific drugs and is known to confer resistance against many chemotherapeutic agents including anthracyclines, paclitaxel, and vincristine but also several protein kinase inhibitors [58, 59]. By employing nanoparticle technology to serve as delivery agents, drug 
efflux is inherently reduced, as nanoparticles enter the cells mainly by endocytosis and facilitate endosomal/lysosomal escape of distinct payloads to the cytosol before their cargo is released [60-62]. Therefore, most of nanoparticle-delivered drugs are less affected by drug efflux pumps due to their location inside the cell, usually outside the reach of membrane efflux pumps [13, 63-65]. Albeit, while the drug efflux pumps are partially bypassed by encapsulating drugs in nanoparticles, the effect is not absolute, as once the drugs are released inside the cells, a portion of the drug may still become in reach of efflux pumps. In that sense, it may be prudent to actively co-inhibit efflux pumps while delivering drugs to the targets cells. For this purpose, Xu et al. [66] reported that drug efflux-mediated resistance in lung cancer cells could be effectively overcome by coating nanoparticles containing doxorubicin with cyclosporin $\mathrm{A}$, which is a multimodal efflux pump inhibitor of both $P$-glycoprotein and MRP1 (ABCC1).

Alternatively, the co-delivery of a chemosensitizer, such as curcumin (diferuloylmethane), may considerably decrease drug efflux. Curcumin is a relatively non-toxic plant derived polyphenol that has been described to have anti-carcinogenic effects, mainly mediated by pathway rewiring and interfering with the cell cycle [67-70]. It is also described as a potent inhibitor of the nuclear factor kappa-light-chain-enhancer of activated B cells (NF- $\kappa \mathrm{B}$ ) pathway, as well as a strong suppressor of $\mathrm{ABC}$ transporters, including $P$-glycoprotein, MRP1, and BCRP [69, 71, 72]. However, curcumin by itself has a poor uptake by the intestinal tract and a notable low bioavailability, which makes this compound an ideal candidate to be integrated in nanoparticles approaches for targeted delivery [73]. Distinct multi-compound nanoparticle approaches that address cancer mechanisms of resistance, including curcumin co-encapsulation, are summarized in Table 3.

There are several studies of nanoparticle encapsulated drug combinations with curcumin available in the literature that shown efficient circumvention of multidrug resistance in a variety of models. For instance, Pramanik and colleagues [74] have shown that doxorubicin-curcumin amphiphilic polymer-based nanoparticles successfully overcome drug efflux mediated resistance, reduced cardiotoxicity, and bone marrow suppression compared to 'free' DOX and Doxil ${ }^{\circledR}$ in several cancer models. Successful reversal of chemo sensitivity has also been described by several other groups. For example, Duan et al. [75] have reported the successful reversal of drug efflux-mediated resistance in an adriamycin-resistant cell line by the simultaneous delivery of doxorubicin and curcumin in poly (butyl cyanoacrylate) nanoparticles. The inclusion of curcumin and cytotoxic drugs in nanoparticle formulations appears to be a logical strategy to circumvent, in a non-exclusive manner, efflux pump mediated cancer therapy resistance and possibly other mechanisms of resistance, accompanied with low toxicity to non-cancerous tissue. It should, however, be mentioned that these experiments were all performed in preclinical models with relatively high induced $P$-glycoprotein expression, a condition that has not been found in patients with solid tumors, but only in some hematological malignancies.

\section{Conclusion and outlook}

Nanoparticles are evolving from general, non-targeted, mono-drug delivery devices to become sophisticated multidrug, targeted, sequence, and time controlled drug release delivery devices. Moreover, nanoparticles can be designed to deliver drugs to cancer cells in a highly efficient manner while at the same time be able to address existing mechanisms of resistance. It is even possible to disrupt complex resistance mechanisms that require a sequence specific inhibition of pathways to bypass drug resistance. This will pave the way for the design of highly efficient, multi-functional, personalized theranostic nanomedicine [76]. This can be of immense benefit, for example, when cancer whole-genome sequencing becomes of age. This will allow specifically tailored nanoparticles to be made that can target individual cancer characteristics while therapy progression is tracked in real time by following the included imaging or reporter molecules [77]. Besides rewiring of pathways in cancer cells that overcome mechanisms of resistance to cytolytic drugs, the same design principle may be applied to modulate the tumor microenvironment. For example, modulation of specific pathways that stimulate immune suppressive cells may be interesting candidates for targeted pathway rewiring as described by Kawakami et al. [78]. The authors provide a considerable repertoire of possible targets that are involved in maintaining an immuno-suppressed environment, including STAT3, IL10, and TGF $\beta$, or even immune modulatory antibodies [79].

As described above, several ABC efflux pumps, such as MRPs and BCRP, are upregulated in many cancer types and often found to be involved in conferring resistance against numerous oncological drugs. Several nanoparticle-based strategies have been published addressing these mechanisms of resistance (Tables 2, 3). Indeed, it appears that combining cytostatic drugs with efflux pump inhibitors increases the therapy efficacy considerably.

On the other hand, there are still obstacles that need to be overcome before nanoparticles may become successful and widely available clinical modalities [14]. Out of several, two important obstacles are: (1) the dependence of the EPR effect to gain access to target cells in solid tumors; (2) designing nanoparticles that can be assembled according to GMP regulations without becoming excessively complex and expensive to produce. These issues can be solved by 
Table 3 Nanoparticle (multiple) compound delivery targeting pathways involved in therapy resistance

\begin{tabular}{|c|c|c|c|c|c|}
\hline Nanoparticle type & Active targeting & Compounds & $\begin{array}{l}\text { Primary method of resist- } \\
\text { ance targeted }^{\mathrm{b}}\end{array}$ & Model & References \\
\hline Amphiphilic polymer & - & Curcumin + doxorubicin & ABC pumps/NF-кB & $\begin{array}{l}\text { Human multiple mye- } \\
\text { loma, acute leukemia, } \\
\text { prostate and ovarian } \\
\text { cancers }\end{array}$ & {$[74]$} \\
\hline $\begin{array}{l}\text { Cationic amphiphilic } \\
\text { copolymer }\end{array}$ & - & $\begin{array}{l}\text { IL12 plasmid + Pacli- } \\
\text { taxel }\end{array}$ & Immune suppression & Murine breast cancer & [118] \\
\hline Chitosan based & - & Curcumin + doxorubicin & ABC pumps/NF-кB & $\begin{array}{l}\text { Human breast cancer (in } \\
\text { vitro) }\end{array}$ & {$[75]$} \\
\hline Dendrimer & $\begin{array}{l}\text { Transferrin receptor- } \\
\text { specific peptide }\end{array}$ & TRAIL + doxorubicin & FADD & Human liver cancer & [119] \\
\hline Flaxseed oil emulsion & - & Curcumin + paclitaxel & ABC pumps/NF-кB & $\begin{array}{l}\text { Human ovarian adeno- } \\
\text { carcinoma (in vitro) }\end{array}$ & [120] \\
\hline Gel-liposome & Hyaluronic acid & TRAIL + doxorubicin & FADD & Human breast cancer & [121] \\
\hline Graphene & - & TRAIL + doxorubicin & FADD & Human lung cancer & [122] \\
\hline Lipid & - & Curcumin + doxorubicin & ABC pumps/NF-кB & Human liver cancer & [123] \\
\hline Liposomal & RGDK-lipopeptide & Curcumin + doxorubicin & $\begin{array}{l}\text { ABC pumps/anti-angi- } \\
\text { ogenic }\end{array}$ & Murine melanoma & [124] \\
\hline Liposomal & DQA & $\begin{array}{l}\text { Lonidamine }+ \text { epirubicin } \\
\text { (in a separate liposomal } \\
\text { formulation) }\end{array}$ & $\begin{array}{l}\text { Mitochondrial hexoki- } \\
\text { nase } 2\end{array}$ & Human lung cancer & {$[125]$} \\
\hline Liposomal & - & $\begin{array}{l}\text { TRAIL + doxorubicin (in } \\
\text { separate nanoparticles) }\end{array}$ & FADD & Human lung cancer & [126] \\
\hline $\begin{array}{l}\text { Liposomal (plus [D]- } \\
\mathrm{H}_{6} \mathrm{~L}_{9} \text { ) }\end{array}$ & - & MiR-10b + paclitaxel & RhoC & Murine breast cancer & {$[127]$} \\
\hline Liposomal (plus MG) & Her-2 antibody & Verapamil + doxorubicin & P-glycoprotein & Human breast cancer & [128] \\
\hline Micellar based & - & Curcumin + doxorubicin & ABC pumps/NF-кB & Murine lung cancer & [129] \\
\hline Micellar based & - & $\begin{array}{l}\text { Disulfiram + Doxoru- } \\
\text { bicin }\end{array}$ & P-glycoprotein & Human breast cancer & [130] \\
\hline PCDA based & Biotin & Curcumin + doxorubicin & P-glycoprotein & Human breast cancer & [131] \\
\hline PLGA based & EGFR-peptide & Paclitaxel + lonidamine & $\begin{array}{l}\text { Mitochondrial hexoki- } \\
\text { nase } 2\end{array}$ & $\begin{array}{l}\text { Human breast and ovar- } \\
\text { ian cancer }\end{array}$ & {$[132,133]$} \\
\hline PLGA & - & $\begin{array}{l}\text { Cyclosporin A + doxo- } \\
\text { rubicin }\end{array}$ & P-glycoprotein & Human lung cancer & {$[66]$} \\
\hline PLGA & Anti-EGFR antibody ${ }^{\mathrm{a}}$ & Rapamycin & mTOR & $\begin{array}{l}\text { Human breast cancer (in } \\
\text { vitro) }\end{array}$ & [134] \\
\hline PLGA & Folate & Nutlin-3a + curcumin & ABC pumps/NF-кB & $\begin{array}{l}\text { Human retinoblastoma } \\
\text { (in vitro) }\end{array}$ & [135] \\
\hline PLGA & - & $\begin{array}{l}\text { HPI-1 + Gemcitabine } \\
\text { (Gemcitabine not in } \\
\text { nanoparticle) }\end{array}$ & Hedgehog/Smo & $\begin{array}{l}\text { Murine medulloblas- } \\
\text { toma, human pancreatic } \\
\text { and liver cancer }\end{array}$ & {$[136,137]$} \\
\hline PLGA & - & Curcumin + doxorubicin & ABC pumps/NF-кB & $\begin{array}{l}\text { Human chronic myelog- } \\
\text { enous leukemia (in } \\
\text { vitro) }\end{array}$ & [138] \\
\hline PLGA & Biotin & $\begin{array}{l}\text { Tariquidar }+ \\
\text { paclitaxel }\end{array}$ & P-glycoprotein & Murine mammary tumor & [139] \\
\hline PLGA & iRGD & $\begin{array}{l}\text { Camptothecin + TRAIL } \\
\text { plasmid }\end{array}$ & FADD & Human colon cancer & [140] \\
\hline PLGA & Anisamide & Resveratrol + doxorubicin & ABC pumps/NF-кB & Human breast cancer & [141] \\
\hline
\end{tabular}

$D Q A$ dequalinium, $F A D D$ Fas-associated protein with death domain, $M G$ Malachite green carbinol base, $F A D D$ Fas-associated protein with Death Domain, PCDA Poly(curcumin-dithiodipropionic acid), PLGA Poly(lactic-co-glycolic acid), RhoC Ras homolog gene family, member C, TRAIL tumor necrosis factor-related apoptosis-inducing ligand

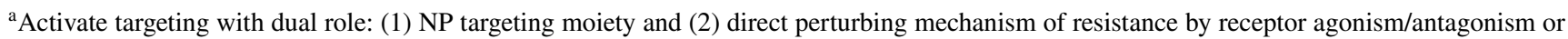
trigger antibody induced cytotoxicity

${ }^{\mathrm{b}}$ The described inhibitor mode of action is pleiotropic and may have several targets other than described 
emerging technologies. For instance, the dependence of the EPR effect may be effectively reduced by the design of nanoparticles that stimulate specific transcytosis [80] or combined with photodynamic therapy to enhance nanoparticle accumulation specifically in tumors [81, 82].

To conclude, when curative cancer surgery fails or is not feasible, there is currently no effective curative alternative treatment for chemotherapy resistant solid tumors. Despite the obstacles that need resolving, dexterous, and specifically formulated multi-compound and multi-functional nanoparticles may become a viable modality for the treatment of non-resectable and chemotherapy resistant cancer in the foreseeable future.

Acknowledgements Conception of idea: LJ Cruz and CG Da Silva; CG Da Silva collected the initial literature, generated the graphical illustrations and drafted the first version; Godefridus J Peters, Ferry Ossendorp and Luis J. Cruz revised the paper and made final additions.

\section{Compliance with Ethical Standards}

Funding This study was funded by the research program 723.012.110 (Vidi), which is financed by the Netherlands Organisation for Scientific Research (NWO) and by the FP7 European Union Marie Curie IAPP program, BRAINPATH, under Grant Number 612360 (EvB, MS, AC, CL) and funding from the H2020-Marie SkłodowskaCurie Action Research and Innovation Staff Exchange (RISE) Grant 644373-PRISAR.

Conflict of interest The authors declare that they have no conflict of interest.

Ethical approval This article does not contain any studies with human participants or animals performed by any of the authors.

Informed consent Not applicable.

Open Access This article is distributed under the terms of the Creative Commons Attribution 4.0 International License (http://creativecommons.org/licenses/by/4.0/), which permits unrestricted use, distribution, and reproduction in any medium, provided you give appropriate credit to the original author(s) and the source, provide a link to the Creative Commons license, and indicate if changes were made.

\section{References}

1. Da Silva CG, Rueda F, Löwik CW et al (2016) Combinatorial prospects of nano-targeted chemoimmunotherapy. Biomaterials 83:308-320. doi:10.1016/j.biomaterials.2016.01.006

2. Srinivas M, Tel J, Schreibelt G et al (2015) PLGA-encapsulated perfluorocarbon nanoparticles for simultaneous visualization of distinct cell populations by 19F MRI. Nanomedicine (Lond) 10:2339-2348. doi:10.2217/NNM.15.76

3. Srinivas M, Cruz LJ, Bonetto F et al (2010) Customizable, multifunctional fluorocarbon nanoparticles for quantitative in vivo imaging using 19F MRI and optical imaging. Biomaterials 31:7070-7077. doi:10.1016/j.biomaterials.2010.05.069
4. Cruz LJ, Stammes MA, Que I et al (2016) Effect of PLGA NP size on efficiency to target traumatic brain injury. J Control Release 223:31-41. doi:10.1016/j.jconrel.2015.12.029

5. Cruz LJ, Que I, Aswendt M et al (2016) Targeted nanoparticles for the non-invasive detection of traumatic brain injury by optical imaging and fluorine magnetic resonance imaging. Nano Res 9:1276-1289. doi:10.1007/s12274-016-1023-Z

6. Naseri N, Valizadeh H, Zakeri-Milani P (2015) Solid lipid nanoparticles and nanostructured lipid carriers: structure, preparation and application. Adv Pharm Bull 5:305-313. doi:10.15171/ apb.2015.043

7. Hosta-Rigau L, Olmedo I, Arbiol J et al (2010) Multifunctionalized gold nanoparticles with peptides targeted to gastrinreleasing peptide receptor of a tumor cell line. Bioconjug Chem 21:1070-1078. doi:10.1021/bc1000164

8. Hosta L, Pla-Roca M, Arbiol J et al (2009) Conjugation of Kahalalide F with Gold Nanoparticles to Enhance in vitro antitumoral activity. Bioconjug Chem 20:138-146. doi:10.1021/bc800362j

9. Kogan MJ, Olmedo I, Hosta L et al (2007) Peptides and metallic nanoparticles for biomedical applications. Nanomedicine 2:287-306. doi:10.2217/17435889.2.3.287

10. Schütz CA, Juillerat-Jeanneret L, Mueller H et al (2013) Therapeutic nanoparticles in clinics and under clinical evaluation. Nanomedicine (Lond) 8:449-467. doi:10.2217/nnm.13.8

11. van der Meel R, Vehmeijer LJC, Kok RJ et al (2013) Ligandtargeted particulate nanomedicines undergoing clinical evaluation: current status. Adv Drug Deliv Rev 65:1284-1298. doi:10.1016/j.addr.2013.08.012

12. Bobo D, Robinson KJ, Islam J et al (2016) Nanoparticlebased medicines: a review of FDA-approved materials and clinical trials to date. Pharm Res 33:2373-2387. doi:10.1007/ s11095-016-1958-5

13. Davis ME, Chen ZG, Shin DM (2008) Nanoparticle therapeutics: an emerging treatment modality for cancer. Nat Rev Drug Discov 7:771-782. doi:10.1038/nrd2614

14. Park K (2013) Facing the truth about nanotechnology in drug delivery. ACS Nano 7:7442-7447. doi:10.1021/nn404501g

15. Acharya S, Sahoo SK (2011) PLGA nanoparticles containing various anticancer agents and tumour delivery by EPR effect. Adv Drug Deliv Rev 63:170-183. doi:10.1016/j.addr.2010.10.008

16. Fang J, Nakamura H, Maeda H (2011) The EPR effect: unique features of tumor blood vessels for drug delivery, factors involved, and limitations and augmentation of the effect. Adv Drug Deliv Rev 63:136-151. doi:10.1016/j.addr.2010.04.009

17. Kobayashi H, Watanabe R, Choyke PL (2013) Improving conventional enhanced permeability and retention (EPR) effects; what is the appropriate target? Theranostics 4:81-89. doi:10.7150/ thno.7193

18. Pantziarka P, Bouche G, Meheus L et al (2014) The repurposing drugs in oncology (ReDO) project. Ecancermedicalscience 8:442. doi:10.3332/ecancer.2014.442

19. Semete B, Booysen L, Lemmer Y et al (2010) In vivo evaluation of the biodistribution and safety of PLGA nanoparticles as drug delivery systems. Nanomedicine 6:662-671. doi:10.1016/j. nano.2010.02.002

20. Milla P, Dosio F, Cattel L (2012) PEGylation of proteins and liposomes: a powerful and flexible strategy to improve the drug delivery. Curr Drug Metab 13:105-119

21. Palombo M, Deshmukh M, Myers D et al (2014) Pharmaceutical and toxicological properties of engineered nanomaterials for drug delivery. Annu Rev Pharmacol Toxicol 54:581-598. doi:10.1146/annurev-pharmtox-010611-134615

22. Fodale V, Pierobon M, Liotta L, Petricoin E (2011) Mechanism of cell adaptation: when and how do cancer cells develop chemoresistance? Cancer J 17:89-95. doi:10.1097/ PPO.0b013e318212dd3d 
23. Ahmed M, Li L-C (2013) Adaptation and clonal selection models of castration-resistant prostate cancer: current perspective. Int J Urol 20:362-371. doi:10.1111/iju.12005

24. Housman G, Byler S, Heerboth S et al (2014) Drug resistance in cancer: an overview. Cancers (Basel) 6:1769-1792. doi:10.3390/ cancers6031769

25. Dhillon AS, Hagan S, Rath O, Kolch W (2007) MAP kinase signalling pathways in cancer. Oncogene 26:3279-3290. doi:10.1038/sj.onc.1210421

26. Felsher DW, Bishop JM (1999) Transient excess of MYC activity can elicit genomic instability and tumorigenesis. Proc Natl Acad Sci 96:3940-3944. doi:10.1073/pnas.96.7.3940

27. Arvanitis C, Felsher DW (2005) Conditionally MYC: insights from novel transgenic models. Cancer Lett 226:95-99. doi:10.1016/j.canlet.2004.10.043

28. Jain M, Arvanitis C, Chu K et al (2002) Sustained loss of a neoplastic phenotype by brief inactivation of MYC. Science 297:102-104. doi:10.1126/science.1071489

29. Dang CV (2012) MYC on the path to cancer. Cell 149:22-35. doi:10.1016/j.cell.2012.03.003

30. Gottesman MM, Fojo T, Bates SE (2002) multidrug resistance in cancer: role of ATP-dependent transporters. Nat Rev Cancer 2:48-58. doi:10.1038/nrc706

31. Goldberg MS, Hook SS, Wang AZ et al (2013) Biotargeted nanomedicines for cancer: six tenets before you begin. Nanomedicine (Lond) 8:299-308. doi:10.2217/nnm.13.3

32. Tyner K, Sadrieh N (2011) Considerations when submitting nanotherapeutics to FDA/CDER for regulatory review. Methods Mol Biol 697:17-31. doi:10.1007/978-1-60327-198-1_3

33. Chen Y, Fu L (2011) Mechanisms of acquired resistance to tyrosine kinase inhibitors. Acta Pharm Sin B 1:197-207. doi:10.1016/j.apsb.2011.10.007

34. Marslin G, Sheeba CJ, Kalaichelvan VK et al (2009) Poly(D, L-lactic-co-glycolic acid) nanoencapsulation reduces Erlotinib-induced subacute toxicity in rat. J Biomed Nanotechnol 5:464-471

35. Marslin G, Revina AM, Khandelwal VKM et al (2015) Delivery as nanoparticles reduces imatinib mesylate-induced cardiotoxicity and improves anticancer activity. Int J Nanomed 10:31633170. doi:10.2147/IJN.S75962

36. Basu S, Harfouche R, Soni S et al (2009) Nanoparticle-mediated targeting of MAPK signaling predisposes tumor to chemotherapy. Proc Natl Acad Sci USA 106:7957-7961. doi:10.1073/ pnas.0902857106

37. Lee MJ, Ye AS, Gardino AK et al (2012) Sequential application of anticancer drugs enhances cell death by rewiring apoptotic signaling networks. Cell 149:780-794. doi:10.1016/j. cell.2012.03.031

38. Morton SW, Lee MJ, Deng ZJ et al (2014) A nanoparticle-based combination chemotherapy delivery system for enhanced tumor killing by dynamic rewiring of signaling pathways. Sci Signal 7:ra44. doi:10.1126/scisignal.2005261

39. Au KM, Min Y, Tian X et al (2015) Improving cancer chemoradiotherapy treatment by dual controlled release of wortmannin and docetaxel in polymeric nanoparticles. ACS Nano. doi:10.1021/ acsnano. 5 b02913

40. Avan A, Narayan R, Giovannetti E, Peters GJ (2016) Role of Akt signaling in resistance to DNA-targeted therapy. World J Clin Oncol 7:352. doi:10.5306/wjco.v7.i5.352

41. Wheeler DL, Dunn EF, Harari PM (2010) Understanding resistance to EGFR inhibitors-impact on future treatment strategies. Nat Rev Clin Oncol 7:493-507. doi:10.1038/nrclinonc.2010.97

42. van der Meel R, Oliveira S, Altintas I et al (2013) Inhibition of tumor growth by targeted anti-EGFR/IGF-1R nanobullets depends on efficient blocking of cell survival pathways. Mol Pharm 10:3717-3727. doi:10.1021/mp400212v
43. Da Silva CG, Honeywell RJ, Dekker H, Peters GJ (2015) Physicochemical properties of novel protein kinase inhibitors in relation to their substrate specificity for drug transporters. Expert Opin Drug Metab Toxicol 11:703-717. doi:10.1517/17425255. 2015.1006626

44. Wilson RC, Doudna JA (2013) Molecular mechanisms of RNA interference. Annu Rev Biophys 42:217-239. doi:10.1146/ annurev-biophys-083012-130404

45. Yin H, Kanasty RL, Eltoukhy AA et al (2014) Non-viral vectors for gene-based therapy. Nat Rev Genet 15:541-555. doi:10.1038/ nrg3763

46. Kay MA (2011) State-of-the-art gene-based therapies: the road ahead. Nat Rev Genet 12:316-328. doi:10.1038/nrg2971

47. Kiang A, Hartman ZC, Everett RS et al (2006) Multiple innate inflammatory responses induced after systemic adenovirus vector delivery depend on a functional complement system. Mol Ther 14:588-598. doi:10.1016/j.ymthe.2006.03.024

48. Ma Z, Li J, He F et al (2005) Cationic lipids enhance siRNAmediated interferon response in mice. Biochem Biophys Res Commun 330:755-759. doi:10.1016/j.bbrc.2005.03.041

49. Zalipsky S (1995) Chemistry of polyethylene glycol conjugates with biologically active molecules. Adv Drug Deliv Rev 16:157182. doi:10.1016/0169-409X(95)00023-Z

50. Yoon HY, Son S, Lee SJ et al (2014) Glycol chitosan nanoparticles as specialized cancer therapeutic vehicles: sequential delivery of doxorubicin and Bcl-2 siRNA. Sci Rep 4:6878. doi:10.1038/srep06878

51. Zhang Y, Peng L, Mumper RJ, Huang L (2013) Combinational delivery of c-myc siRNA and nucleoside analogs in a single, synthetic nanocarrier for targeted cancer therapy. Biomaterials 34:8459-8468. doi:10.1016/j.biomaterials.2013.07.050

52. Zhang Y, Schwerbrock NM, Rogers AB et al (2013) Codelivery of VEGF siRNA and gemcitabine monophosphate in a single nanoparticle formulation for effective treatment of NSCLC. Mol Ther 21:1559-1569. doi:10.1038/mt.2013.120

53. Adema AD, Bijnsdorp IV, Sandvold ML et al (2009) Innovations and opportunities to improve conventional (deoxy)nucleoside and fluoropyrimidine analogs in cancer. Curr Med Chem $16: 4632-4643$

54. Peters GJ (2014) Novel Developments in the Use of Antimetabolites. Nucleosides, Nucleotides Nucleic Acids 33:358-374. doi:1 0.1080/15257770.2014.894197

55. Hooijberg JH, de Vries NA, Kaspers GJL et al (2006) Multidrug resistance proteins and folate supplementation: therapeutic implications for antifolates and other classes of drugs in cancer treatment. Cancer Chemother Pharmacol 58:1-12. doi:10.1007/ s00280-005-0141-1

56. Swain SM, Whaley FS, Ewer MS (2003) Congestive heart failure in patients treated with doxorubicin: a retrospective analysis of three trials. Cancer 97:2869-2879. doi:10.1002/cncr.11407

57. Gottesman MM, Pastan IH (2015) The role of multidrug resistance efflux pumps in cancer: revisiting a JNCI publication exploring expression of the MDR1 (P-glycoprotein) Gene. J Natl Cancer Inst 107:djv222. doi:10.1093/jnci/djv222

58. Nobili S, Landini I, Mazzei T, Mini E (2012) Overcoming tumor multidrug resistance using drugs able to evade $P$-glycoprotein or to exploit its expression. Med Res Rev 32:1220-1262. doi:10.1002/med.20239

59. Lemos C, Jansen G, Peters GJ (2008) Drug transporters: recent advances concerning BCRP and tyrosine kinase inhibitors. Br J Cancer 98:857-862. doi:10.1038/sj.bjc.6604213

60. Cruz LJ, Tacken PJ, Bonetto F et al (2011) Multimodal imaging of nanovaccine carriers targeted to human dendritic cells. Mol Pharm 8:520-531. doi: $10.1021 / \mathrm{mp} 100356 \mathrm{k}$

61. Cruz LJ, Tacken PJ, Zeelenberg IS et al (2014) Tracking targeted bimodal nanovaccines: immune responses and routing in 
cells, tissue, and whole organism. Mol Pharm 11:4299-4313. doi:10.1021/mp400717r

62. Cruz LJ, Tacken PJ, Eich C et al (2017) Controlled release of antigen and Toll-like receptor ligands from PLGA nanoparticles enhances immunogenicity. Nanomedicine 12:491-510. doi:10.2217/nnm-2016-0295

63. Dong X, Mattingly CA, Tseng MT et al (2009) Doxorubicin and paclitaxel-loaded lipid-based nanoparticles overcome multidrug resistance by inhibiting $P$-glycoprotein and depleting ATP. Cancer Res 69:3918-3926. doi:10.1158/0008-5472.CAN-08-2747

64. Liang X-J, Meng H, Wang Y et al (2010) Metallofullerene nanoparticles circumvent tumor resistance to cisplatin by reactivating endocytosis. Proc Natl Acad Sci USA 107:7449-7454. doi:10.1073/pnas.0909707107

65. Zeng X, Morgenstern R, Nyström AM (2014) Nanoparticledirected sub-cellular localization of doxorubicin and the sensitization breast cancer cells by circumventing GST-mediated drug resistance. Biomaterials 35:1227-1239. doi:10.1016/j. biomaterials.2013.10.042

66. Xu L, Li H, Wang Y et al (2014) Enhanced activity of doxorubicin in drug resistant A549 tumor cells by encapsulation of $P$-glycoprotein inhibitor in PLGA-based nanovectors. Oncol Lett 7:387-392. doi:10.3892/ol.2013.1711

67. Sa G, Das T (2008) Anti cancer effects of curcumin: cycle of life and death. Cell Div 3:14. doi:10.1186/1747-1028-3-14

68. Choi BH, Kim CG, Lim Y et al (2008) Curcumin down-regulates the multidrug-resistance mdr1b gene by inhibiting the PI3 K/Akt/ NF kappa B pathway. Cancer Lett 259:111-118. doi:10.1016/j. canlet.2007.10.003

69. Chearwae W, Wu C-P, Chu H-Y et al (2006) Curcuminoids purified from turmeric powder modulate the function of human multidrug resistance protein 1 (ABCC1). Cancer Chemother Pharmacol 57:376-388. doi:10.1007/s00280-005-0052-1

70. Chearwae W, Anuchapreeda S, Nandigama K et al (2004) Biochemical mechanism of modulation of human $P$-glycoprotein (ABCB1) by curcumin I, II, and III purified from Turmeric powder. Biochem Pharmacol 68:2043-2052. doi:10.1016/j. bcp.2004.07.009

71. Aggarwal BB, Shishodia S, Takada Y et al (2005) Curcumin suppresses the paclitaxel-induced nuclear factor-kappaB pathway in breast cancer cells and inhibits lung metastasis of human breast cancer in nude mice. Clin Cancer Res 11:7490-7498. doi:10.1158/1078-0432.CCR-05-1192

72. Limtrakul P, Chearwae W, Shukla S et al (2007) Modulation of function of three $\mathrm{ABC}$ drug transporters, $P$-glycoprotein (ABCB1), mitoxantrone resistance protein (ABCG2) and multidrug resistance protein 1 (ABCC1) by tetrahydrocurcumin, a major metabolite of curcumin. Mol Cell Biochem 296:85-95. doi:10.1007/s11010-006-9302-8

73. Sharma RA, McLelland HR, Hill KA et al (2001) Pharmacodynamic and pharmacokinetic study of oral Curcuma extract in patients with colorectal cancer. Clin Cancer Res 7:1894-1900

74. Pramanik D, Campbell NR, Das S et al (2012) A composite polymer nanoparticle overcomes multidrug resistance and ameliorates doxorubicin-associated cardiomyopathy. Oncotarget 3:640-650

75. Duan J, Mansour HM, Zhang Y et al (2012) Reversion of multidrug resistance by co-encapsulation of doxorubicin and curcumin in chitosan/poly(butyl cyanoacrylate) nanoparticles. Int J Pharm 426:193-201. doi:10.1016/j.ijpharm.2012.01.020

76. Pene F, Courtine E, Cariou A, Mira J-P (2009) Toward theragnostics. Crit Care Med 37:S50-S58. doi:10.1097/ CCM.0b013e3181921349

77. Bao G, Mitragotri S, Tong S (2013) Multifunctional nanoparticles for drug delivery and molecular imaging. Annu Rev Biomed Eng 15:253-282. doi:10.1146/annurev-bioeng-071812-152409
78. Kawakami Y, Yaguchi T, Sumimoto H et al (2013) Cancerinduced immunosuppressive cascades and their reversal by molecular-targeted therapy. Ann N Y Acad Sci 1284:80-86. doi:10.1111/nyas.12094

79. Rahimian S, Fransen MF, Kleinovink JW et al (2015) Polymeric microparticles for sustained and local delivery of antiCD40 and antiCTLA-4 in immunotherapy of cancer. Biomaterials 61:3340. doi:10.1016/j.biomaterials.2015.04.043

80. Lu W, Xiong C, Zhang R et al (2012) Receptor-mediated transcytosis: a mechanism for active extravascular transport of nanoparticles in solid tumors. J Control Release 161:959-966. doi:10.1016/j.jconrel.2012.05.014

81. Gao W, Wang Z, Lv L et al (2016) Photodynamic therapy induced enhancement of tumor vasculature permeability using an upconversion nanoconstruct for improved intratumoral nanoparticle delivery in deep tissues. Theranostics 6:1131-1144. doi:10.7150/thno. 15262

82. Zhen Z, Tang W, Chuang Y-J et al (2014) Tumor vasculature targeted photodynamic therapy for enhanced delivery of nanoparticles. ACS Nano 8:6004-6013. doi:10.1021/nn501134q

83. Ashton S, Song YH, Nolan J et al (2016) Aurora kinase inhibitor nanoparticles target tumors with favorable therapeutic index in vivo. Sci Transl, Med, p 8

84. Altintas I, Heukers R, van der Meel R et al (2013) Nanobodyalbumin nanoparticles (NANAPs) for the delivery of a multikinase inhibitor 17864 to EGFR overexpressing tumor cells. J Control Release 165:110-118. doi:10.1016/j.jconrel.2012.11.007

85. Lam ATN, Yoon J, Ganbold E-O et al (2014) Adsorption and desorption of tyrosine kinase inhibitor erlotinib on gold nanoparticles. J Colloid Interface Sci 425:96-101. doi:10.1016/j. jcis.2014.03.032

86. Lam ATN, Yoon J, Ganbold E-O et al (2014) Colloidal gold nanoparticle conjugates of gefitinib. Colloids Surf B Biointerfaces 123:61-67. doi:10.1016/j.colsurfb.2014.08.021

87. Zhang X, Xie L, Zheng M et al (2015) Aurora kinase inhibitors attached to iron oxide nanoparticles enhances inhibition of the growth of liver cancer cells. J Nanoparticle Res 17:247. doi:10.1007/s11051-014-2708-4

88. Uckun FM, Dibirdik I, Qazi S, Yiv S (2010) Therapeutic nanoparticle constructs of a JAK3 tyrosine kinase inhibitor against human B-lineage ALL cells. Arzneimittelforschung 60:210-217. doi:10.1055/s-0031-1296275

89. Dibirdik I, Yiv S, Qazi S, Uckun FM (2010) In vivo anticancer activity of a liposomal nanoparticle construct of multifunctional tyrosine kinase inhibitor 4-(4'-Hydroxyphenyl)Amino-6,7-Dimethoxyquinazoline. J Nanomed Nanotechnol. doi:10.4172/2157-7439.1000101

90. Uckun FM, Myers DE, Cheng J, Qazi S (2015) Liposomal nanoparticles of a spleen tyrosine kinase P-site inhibitor amplify the potency of low dose total body irradiation against aggressive B-precursor leukemia and yield superior survival outcomes in mice. EBioMedicine 2:554-562. doi:10.1016/j. ebiom.2015.04.005

91. Myers DE, Yiv S, Qazi S et al (2014) CD19-antigen specific nanoscale liposomal formulation of a SYK P-site inhibitor causes apoptotic destruction of human B-precursor leukemia cells. Integr Biol (Camb) 6:766-780. doi:10.1039/c4ib00095a

92. Uckun FM, Qazi S, Cely I et al (2013) Nanoscale liposomal formulation of a SYK P-site inhibitor against B-precursor leukemia. Blood 121:4348-4354. doi:10.1182/blood-2012-11-470633

93. Dreaden EC, Kong YW, Morton SW et al (2015) Tumor-targeted synergistic blockade of MAPK and PI3K from a layer-by-layer nanoparticle. Clin Cancer Res. doi:10.1158/1078-0432.CCR-150013 (1078-0432.CCR-15-0013-)

94. Palvai S, More P, Mapara N et al (2016) Self-assembled oleic acid nanoparticle mediated inhibition of mitogen-activated protein 
kinase signaling in combination with dna damage in cancer cells. ChemNanoMat 2:201-211. doi:10.1002/cnma.201500195

95. Harfouche R, Basu S, Soni S et al (2009) Nanoparticle-mediated targeting of phosphatidylinositol-3-kinase signaling inhibits angiogenesis. Angiogenesis 12:325-338. doi:10.1007/ s10456-009-9154-4

96. Vrignaud S, Hureaux J, Wack S et al (2012) Design, optimization and in vitro evaluation of reverse micelle-loaded lipid nanocarriers containing erlotinib hydrochloride. Int J Pharm 436:194-200. doi:10.1016/j.ijpharm.2012.06.026

97. Saad M, Garbuzenko OB, Minko T (2008) Co-delivery of siRNA and an anticancer drug for treatment of multidrug-resistant cancer. Nanomedicine (Lond) 3:761-776. doi:10.2217/17435889.3.6.761

98. Chen Y, Wu JJ, Huang L (2010) Nanoparticles targeted with NGR motif deliver c-myc siRNA and doxorubicin for anticancer therapy. Mol Ther 18:828-834. doi:10.1038/mt.2009.291

99. Chen Y, Bathula SR, Li J, Huang L (2010) Multifunctional nanoparticles delivering small interfering RNA and doxorubicin overcome drug resistance in cancer. J Biol Chem 285:22639-22650. doi:10.1074/jbc.M110.125906

100. Chen Y, Zhu X, Zhang X et al (2010) Nanoparticles modified with tumor-targeting scFv deliver siRNA and miRNA for cancer therapy. Mol Ther 18:1650-1656. doi:10.1038/mt.2010.136

101. Shim G, Han S-E, Yu Y-H et al (2011) Trilysinoyl oleylamidebased cationic liposomes for systemic co-delivery of siRNA and an anticancer drug. J Control Release 155:60-66. doi:10.1016/j. jconrel.2010.10.017

102. Garbuzenko OB, Saad M, Pozharov VP et al (2010) Inhibition of lung tumor growth by complex pulmonary delivery of drugs with oligonucleotides as suppressors of cellular resistance. Proc Natl Acad Sci USA 107:10737-10742. doi:10.1073/pnas.1004604107

103. Ko YT, Falcao C, Torchilin VP (2009) Cationic liposomes loaded with proapoptotic peptide d-(KLAKLAK) ${ }_{2}$ and Bcl-2 antisense oligodeoxynucleotide G3139 for enhanced anticancer therapy. Mol Pharm 6:971-977. doi:10.1021/mp900006h

104. Deng ZJ, Morton SW, Ben-Akiva E et al (2013) Layer-by-layer nanoparticles for systemic codelivery of an anticancer drug and siRNA for potential triple-negative breast cancer treatment. ACS Nano 7:9571-9584. doi:10.1021/nn4047925

105. Xu Z, Zhang Z, Chen Y et al (2010) The characteristics and performance of a multifunctional nanoassembly system for the co-delivery of docetaxel and iSur-pDNA in a mouse hepatocellular carcinoma model. Biomaterials 31:916-922. doi:10.1016/j. biomaterials.2009.09.103

106. Liu X-Q, Xiong M-H, Shu X-T et al (2012) Therapeutic delivery of siRNA silencing HIF-1 alpha with micellar nanoparticles inhibits hypoxic tumor growth. Mol Pharm 9:2863-2874. doi:10.1021/mp300193f

107. Sun T-M, Du J-Z, Yao Y-D et al (2011) Simultaneous delivery of siRNA and paclitaxel via a "two-in-one" micelleplex promotes synergistic tumor suppression. ACS Nano 5:1483-1494. doi:10.1021/nn103349h

108. MacDiarmid JA, Amaro-Mugridge NB, Madrid-Weiss J et al (2009) Sequential treatment of drug-resistant tumors with targeted minicells containing siRNA or a cytotoxic drug. Nat Biotechnol 27:643-651. doi:10.1038/nbt.1547

109. Tang $\mathrm{S}$, Yin $\mathrm{Q}, \mathrm{Su} \mathrm{J}$ et al (2015) Inhibition of metastasis and growth of breast cancer by $\mathrm{pH}$-sensitive poly ( $\beta$-amino ester) nanoparticles co-delivering two siRNA and paclitaxel. Biomaterials 48:1-15. doi:10.1016/j.biomaterials.2015.01.049

110. Zhang L, Lu Z, Zhao Q et al (2011) Enhanced chemotherapy efficacy by sequential delivery of siRNA and anticancer drugs using PEI-grafted graphene oxide. Small 7:460-464. doi:10.1002/ smll.201001522
111. Yadav S, van Vlerken LE, Little SR, Amiji MM (2009) Evaluations of combination MDR-1 gene silencing and paclitaxel administration in biodegradable polymeric nanoparticle formulations to overcome multidrug resistance in cancer cells. Cancer Chemother Pharmacol 63:711-722. doi:10.1007/ s00280-008-0790-y

112. Patil YB, Swaminathan SK, Sadhukha T et al (2010) The use of nanoparticle-mediated targeted gene silencing and drug delivery to overcome tumor drug resistance. Biomaterials 31:358-365. doi:10.1016/j.biomaterials.2009.09.048

113. Sureban SM, May R, Mondalek FG et al (2011) Nanoparticlebased delivery of siDCAMKL-1 increases microRNA-144 and inhibits colorectal cancer tumor growth via a Notch-1 dependent mechanism. J Nanobiotechnol 9:40. doi:10.1186/1477-3155-9-40

114. Xu X, Xie K, Zhang X-Q et al (2013) Enhancing tumor cell response to chemotherapy through nanoparticle-mediated codelivery of siRNA and cisplatin prodrug. Proc Natl Acad Sci USA 110:18638-18643. doi:10.1073/pnas.1303958110

115. Chen AM, Zhang M, Wei D et al (2009) Co-delivery of doxorubicin and Bcl-2 siRNA by mesoporous silica nanoparticles enhances the efficacy of chemotherapy in multidrug-resistant cancer cells. Small 5:2673-2677. doi:10.1002/smll.200900621

116. Meng H, Liong M, Xia T et al (2010) Engineered design of mesoporous silica nanoparticles to deliver doxorubicin and $P$-glycoprotein siRNA to overcome drug resistance in a cancer cell line. ACS Nano 4:4539-4550. doi:10.1021/nn100690m

117. Ding J, Liang T, Zhou Y et al (2017) Hyaluronidase-triggered anticancer drug and siRNA delivery from cascaded targeting nanoparticles for drug-resistant breast cancer therapy. Nano Res 10:690-703. doi:10.1007/s12274-016-1328-y

118. Wang Y, Gao S, Ye W-H et al (2006) Co-delivery of drugs and DNA from cationic core-shell nanoparticles self-assembled from a biodegradable copolymer. Nat Mater 5:791. doi:10.1038/ nmat1737 (publ online 24 Sept 2006)

119. Han L, Huang R, Li J et al (2011) Plasmid pORF-hTRAIL and doxorubicin co-delivery targeting to tumor using peptide-conjugated polyamidoamine dendrimer. Biomaterials 32:1242-1252. doi:10.1016/j.biomaterials.2010.09.070

120. Ganta S, Amiji M (2009) Coadministration of Paclitaxel and curcumin in nanoemulsion formulations to overcome multidrug resistance in tumor cells. Mol Pharm 6:928-939. doi:10.1021/ mp800240j

121. Jiang T, Mo R, Bellotti A et al (2014) Gel-liposome-mediated co-delivery of anticancer membrane-associated proteins and small-molecule drugs for enhanced therapeutic efficacy. Adv Funct Mater 24:2295-2304. doi:10.1002/adfm.201303222

122. Jiang T, Sun W, Zhu Q et al (2015) Furin-mediated sequential delivery of anticancer cytokine and small-molecule drug shuttled by graphene. Adv Mater 27:1021-1028. doi:10.1002/ adma. 201404498

123. Zhao X, Chen Q, Liu W et al (2015) Codelivery of doxorubicin and curcumin with lipid nanoparticles results in improved efficacy of chemotherapy in liver cancer. Int J Nanomed 10:257270. doi:10.2147/IJN.S73322

124. Barui S, Saha S, Mondal G et al (2014) Simultaneous delivery of doxorubicin and curcumin encapsulated in liposomes of pegylated RGDK-lipopeptide to tumor vasculature. Biomaterials 35:1643-1656. doi:10.1016/j.biomaterials.2013.10.074

125. Li N, Zhang C-X, Wang X-X et al (2013) Development of targeting lonidamine liposomes that circumvent drug-resistant cancer by acting on mitochondrial signaling pathways. Biomaterials 34:3366-3380. doi:10.1016/j.biomaterials.2013.01.055

126. Guo L, Fan L, Ren J et al (2011) A novel combination of TRAIL and doxorubicin enhances antitumor effect based on passive tumor-targeting of liposomes. Nanotechnology 22:265105. doi:10.1088/0957-4484/22/26/265105 
127. Zhang Q, Ran R, Zhang L et al (2015) Simultaneous delivery of therapeutic antagomirs with paclitaxel for the management of metastatic tumors by a $\mathrm{pH}$-responsive anti-microbial peptidemediated liposomal delivery system. J Control Release 197:208218. doi:10.1016/j.jconrel.2014.11.010

128. Liu Y, Li L-L, Qi G-B et al (2014) Dynamic disordering of liposomal cocktails and the spatio-temporal favorable release of cargoes to circumvent drug resistance. Biomaterials 35:3406-3415. doi:10.1016/j.biomaterials.2013.12.089

129. Wang B-L, Shen Y, Zhang Q et al (2013) Codelivery of curcumin and doxorubicin by MPEG-PCL results in improved efficacy of systemically administered chemotherapy in mice with lung cancer. Int J Nanomed 8:3521-3531. doi:10.2147/IJN.S45250

130. Duan X, Xiao J, Yin Q et al (2013) Smart pH-sensitive and temporal-controlled polymeric micelles for effective combination therapy of doxorubicin and disulfiram. ACS Nano 7:5858-5869. doi:10.1021/nn4010796

131. Guo S, Lv L, Shen Y et al (2016) A nanoparticulate pre-chemosensitizer for efficacious chemotherapy of multidrug resistant breast cancer. Sci Rep 6:21459. doi:10.1038/srep21459

132. Milane L, Duan Z, Amiji M (2011) Development of EGFRtargeted polymer blend nanocarriers for combination paclitaxel/lonidamine delivery to treat multi-drug resistance in human breast and ovarian tumor cells. Mol Pharm 8:185-203. doi:10.1021/mp1002653

133. Milane L, Duan Z, Amiji M (2011) Therapeutic efficacy and safety of paclitaxel/lonidamine loaded EGFR-targeted nanoparticles for the treatment of multi-drug resistant cancer. PLoS One 6:e24075. doi:10.1371/journal.pone.0024075

134. Acharya S, Dilnawaz F, Sahoo SK (2009) Targeted epidermal growth factor receptor nanoparticle bioconjugates for breast cancer therapy. Biomaterials 30:5737-5750. doi:10.1016/j. biomaterials.2009.07.008

135. Das M, Sahoo SK (2012) Folate decorated dual drug loaded nanoparticle: role of curcumin in enhancing therapeutic potential of nutlin-3a by reversing multidrug resistance. PLoS One 7:e32920. doi:10.1371/journal.pone.0032920

136. Chenna V, Hu C, Pramanik D et al (2012) A polymeric nanoparticle encapsulated small-molecule inhibitor of Hedgehog signaling (NanoHHI) bypasses secondary mutational resistance to Smoothened antagonists. Mol Cancer Ther 11:165-173. doi:10.1158/1535-7163.MCT-11-0341

137. Xu Y, Chenna V, Hu C et al (2012) Polymeric nanoparticleencapsulated hedgehog pathway inhibitor HPI-1 (NanoHHI) inhibits systemic metastases in an orthotopic model of human hepatocellular carcinoma. Clin Cancer Res 18:1291-1302. doi:10.1158/1078-0432.CCR-11-0950

138. Misra R, Sahoo SK (2011) Co-formulation of doxorubicin and curcumin in poly (D, L-lactide-co-glycolide) nanoparticles suppress the development of multi drug resistance in K562 Cells. Mol Pharm 8:852-866. doi:10.1021/mp100455h

139. Patil Y, Sadhukha T, Ma L, Panyam J (2009) Nanoparticlemediated simultaneous and targeted delivery of paclitaxel and tariquidar overcomes tumor drug resistance. J Control Release 136:21-29. doi:10.1016/j.jconrel.2009.01.021

140. Ediriwickrema A, Zhou J, Deng Y, Saltzman WM (2014) Multi-layered nanoparticles for combination gene and drug delivery to tumors. Biomaterials 35:9343-9354. doi:10.1016/j. biomaterials.2014.07.043

141. Zhao Y, Huan M, Liu M et al (2016) Doxorubicin and resveratrol co-delivery nanoparticle to overcome doxorubicin resistance. Sci Rep 6:35267. doi:10.1038/srep35267 